\title{
Effect of indole-3-acetic acid on lead accumulation in maize (Zea mays L.) seedlings and the relevant antioxidant response
}

\author{
Huan-hua Wang ${ }^{\text {a }}$, Xiao-quan Shan ${ }^{\text {a,* }}$, Bei Wen ${ }^{\text {a }}$, \\ Gary Owens ${ }^{b}$, Jing Fang ${ }^{a}$, Shu-zhen Zhang ${ }^{a}$ \\ ${ }^{a}$ State Key Laboratory of Environmental Chemistry and Ecotoxicology, Research Center for Eco-Environmental Sciences, \\ Chinese Academy of Sciences, P.O. Box 2871, Beijing 100085, China \\ ${ }^{\mathrm{b}}$ Center for Environmental Risk Assessment and Remediation, University of South Australia, Mawson Lakes, SA 5095, Australia
}

Received 27 August 2006; received in revised form 14 May 2007; accepted 8 June 2007

\begin{abstract}
The effect of indole-3-acetic acid (IAA) on lead $(\mathrm{Pb})$ accumulation in maize (Zea mays L. cv. TY2) seedlings, and the responses of maize to $\mathrm{Pb}$, IAA or $\mathrm{Pb}+\mathrm{IAA}$ stress were investigated under hydroponic conditions. Exogenous IAA significantly increased $\mathrm{Pb}$ accumulation in roots, but significantly decreased $\mathrm{Pb}$ accumulation in shoots over the culture period of 5 days. Increased $\mathrm{Pb}$ uptake in maize roots partly took place through calcium and potassium channels, and also depended upon membrane potential. Lipid peroxidation in terms of malondialdehyde (MDA) content was enhanced, indicating that $\mathrm{Pb}$ and/or IAA caused oxidative stress in maize seedlings. Under stress conditions the antioxidant defense mechanism was activated. Some antioxidant enzymes such as superoxide dismutase (SOD), peroxidase (POD) and catalase (CAT) were up-regulated compared to the control. $\mathrm{Pb}$, IAA or $\mathrm{Pb}+\mathrm{IAA}$ treatments resulted in a general reduction of macro- and micronutrient contents, especially of $\mathrm{K}$, Ca and $\mathrm{Mn}$. Compared to a single $\mathrm{Pb}$ or IAA treatment, treatment with a combination of $\mathrm{Pb}+\mathrm{IAA}$ induced more severe oxidative stress on maize roots and shoots as inferred from the higher observed MDA and lower nutrient contents. A Fourier transform infrared (FTIR) spectroscopic study indicated that $\mathrm{Pb}$ reacted with the carboxylic acid group of the IAA pyrrole cycle.
\end{abstract}

(C) 2007 Elsevier B.V. All rights reserved.

Keywords: $\mathrm{Ca}^{2+}$ and $\mathrm{K}^{+}$channels; Antioxidant enzyme activity; Lipid peroxidation; Mineral nutrition; Fourier transform infrared spectroscopy

\section{Introduction}

Lead $(\mathrm{Pb})$ is a highly toxic metal which can be potentially harmful to microbes, plants, animals and humans at elevated levels. Therefore, uptake and accumulation of $\mathrm{Pb}$ in plants poses a potentially serious health risk to humans through contamination of the food chain. $\mathrm{Pb}$ causes multiple direct and indirect effects on plant growth and metabolism. Auxins are organic substances that regulate intracellular processes and modify physiological processes in plants. Auxinic herbicides such as 2,4-dichlorophenoxy acetic acid (2,4-D) and auxin phytohormones have been widely used in agriculture. Indole-3-acetic acid (IAA) is the most abundant naturally occurring auxin, well known for its regulatory function in plant growth. López et al. (2004) reported that $0.2 \mathrm{mM} \mathrm{Pb}+10 \mathrm{mM}$ gibberellic acid

\footnotetext{
* Corresponding author. Tel.: +86 1062923560 ; fax: +86 1062923563 .

E-mail address: xiaoquan@ rcees.ac.cn (X.-q. Shan).
}

increased $\mathrm{Pb}$ concentration in alfalfa (Medicago sativa $\mathrm{L}$.) roots by about $40 \%$ compared to treatment with $\mathrm{Pb}$ only. Treatment with $0.2 \mathrm{mM}$ EDTA $+100 \mu \mathrm{M}$ IAA increased $\mathrm{Pb}$ accumulation in leaves of alfalfa by factors of 28 and 6, respectively, when compared to the $\mathrm{Pb}$ content in leaves when exposed to $\mathrm{Pb}$ only or to $\mathrm{Pb}+$ EDTA in combination (López et al., 2005).

Reactive oxygen species (ROS) such as the superoxide anion $\left(\mathrm{O}_{2}{ }^{\bullet-}\right)$, singlet oxygen $\left({ }^{1} \mathrm{O}_{2}\right)$, hydrogen peroxide $\left(\mathrm{H}_{2} \mathrm{O}_{2}\right)$ and the hydroxyl radical $\left(\bullet^{\bullet} \mathrm{OH}\right)$ all induce oxidative damage because they are highly reactive molecules that can oxidize organic compounds and cause lipid peroxidation in a cellular environment. Malondialdehyde (MDA) is one of the major decomposition products of the polyunsaturated fatty acids in biomembranes and has been widely used as an indicator of lipid peroxidation. Many heavy metals, including $\mathrm{Pb}$, are known to induce over production of ROS and consequently enhance lipid peroxidation, decrease the saturated fatty acids and increase the unsaturated fatty acid contents of membranes of several plant species (Halliwell and Gutteridge, 1999; Malecka et al., 2001). IAA also generates 
ROS, excites oxygen intermediates (De Melo et al., 1992; Joo et al., 2005) and increases MDA content in various rat tissues (Celik and Tuluce, 2006).

Plants have evolved a variety of mechanisms to deal with the effects of ROS in cellular compartments. This is generally handled through the production of various antioxidative enzymes, such as superoxide dismutase (SOD), peroxidase (POD) and catalase (CAT). For example, SOD, a metallo-enzyme, can catalyse the dismutation of $\mathrm{O}_{2}{ }^{\bullet-}$ into $\mathrm{H}_{2} \mathrm{O}_{2}$ and $\mathrm{O}_{2}$, and subsequently $\mathrm{H}_{2} \mathrm{O}_{2}$ can be effectively scavenged by CAT and POD. Heavy metal ions can increase the activity of SOD in oat (Avena sativa L.) (Luna et al., 1994) and in rice (Oryza sativa L.) (Verma and Dubey, 2003). Heavy metals may also decrease (Mishra and Choudhuri, 1996) or not affect at all the SOD activity (Cardinales et al., 1984). Peroxidases utilize $\mathrm{H}_{2} \mathrm{O}_{2}$ in the oxidation of various organic and inorganic substrates. Peroxidases utilizing guaiacol as an electron donor in vitro are called guaiacol peroxidases. A strong induction of POD activity in response to $\mathrm{Pb}$ was reported in thale cress (Arabidopsis thaliana (L.) Heynh) (Lummerzheim et al., 1995), rice (Oryza sativa L.) (Verma and Dubey, 2003) and maize (Zea mays L.) calli (Zacchini et al., 2003). However, the inhibition of POD activity due to heavy metals has also been observed in oat leaves (Luna et al., 1994). CAT is a heme-containing enzyme that converts $\mathrm{H}_{2} \mathrm{O}_{2}$ into $\mathrm{H}_{2} \mathrm{O}$ and $\mathrm{O}_{2}$. Generally, CAT activity is increased in plants due to heavy metal stress (Mishra and Choudhuri, 1996). The effect of IAA on antioxidant enzymes is mostly concerned with animals. De Melo et al. (2004) reported that rat neutrophils and lymphocytes in the presence of IAA $(1 \mathrm{mM})$ increased the activities of SOD, CAT and glutathione peroxidase, which could be an attempt at self-protection.

$\mathrm{Pb}$ is one of the most abundant heavy metal pollutants in both aquatic and terrestrial environments while IAA exists in various biologically active compounds, such as herbicides, but there is little information on its negative effect on higher plants. Therefore, an understanding of $\mathrm{Pb}$ and IAA interaction in plants is essential. López et al. (2004, 2005) studied the effect of IAA on $\mathrm{Pb}$ accumulation in alfalfa, but the relevant mechanisms were not discussed. To date there is very little information on the specific responses of maize seedlings to either IAA only or the combined effect of $\mathrm{Pb}+\mathrm{IAA}$ in combination. We hypothesized that exogenous IAA affects $\mathrm{Pb}$ accumulation, causes oxidative stress and activates antioxidant defense mechanisms. The aim of the present research was to study the effect of IAA on $\mathrm{Pb}$ accumulation in maize, and to gather more information on the relevant mechanisms involved. The question of how maize responds to $\mathrm{Pb}$, IAA or $\mathrm{Pb}+\mathrm{IAA}$ stress was also addressed by examining some biochemical changes in the plants including lipid peroxidation, antioxidant enzyme concentration and nutrition level.

\section{Materials and methods}

\subsection{Plant cultivation and treatment}

Maize (Zea mays L. cv. TY2) seeds were obtained from the Chinese Academy of Agricultural Sciences (Beijing, China). Seeds were first surface-sterilized in $3 \%(\mathrm{v} / \mathrm{v}) \mathrm{H}_{2} \mathrm{O}_{2}$ for $30 \mathrm{~min}$, rinsed with deionized water thoroughly and soaked in $2.8 \mathrm{mM}$ $\mathrm{Ca}\left(\mathrm{NO}_{3}\right)_{2}$ for $4 \mathrm{~h}$. Seeds were then germinated on moist filter papers for 4 days in dark and subsequently transferred to a hydroponic solution containing the following nutrients: $0.33 \mathrm{mM} \mathrm{Ca}\left(\mathrm{NO}_{3}\right)_{2}, 0.17 \mathrm{mM} \mathrm{Ca}\left(\mathrm{H}_{2} \mathrm{PO}_{4}\right)_{2}, 0.17 \mathrm{mM} \mathrm{K}_{2} \mathrm{SO}_{4}$, $0.33 \mathrm{mM} \mathrm{MgSO}_{4}, 0.5 \mathrm{mM} \mathrm{NH}_{4} \mathrm{NO}_{3}, 75 \mu \mathrm{M}$ EDTA-Fe, $46 \mu \mathrm{M}$ $\mathrm{H}_{3} \mathrm{BO}_{3}, 9 \mu \mathrm{M} \mathrm{MnSO}_{4}, 0.8 \mu \mathrm{M} \mathrm{ZnSO}_{4}, 0.3 \mu \mathrm{M} \mathrm{CuSO}{ }_{4}$ and $0.8 \mu \mathrm{M} \mathrm{Na} \mathrm{MoO}_{4}$. Selected maize seedlings were floated in culture vessels (three seedlings per vessel). The vessels were covered with black polyethylene film to minimize illumination of the growth solution and fitted with aeration tubes. The solution was buffered to $\mathrm{pH} 5.8$ with $2 \mathrm{mM}$ Mes-Tris. Maize seedlings were grown in a plant growth chamber with day and night temperature of $22^{\circ} \mathrm{C}(16 \mathrm{~h})$ and $15^{\circ} \mathrm{C}(8 \mathrm{~h})$, respectively. A relative humidity between 50 and $60 \%$ and a photon flux intensity of $300 \mu \mathrm{mol} \mathrm{m}{ }^{-2} \mathrm{~s}^{-1}$ were maintained throughout the entire experiment. Nutrient solutions were replaced with fresh nutrient solutions every other day. In all treatment studies, 10-day-old uniform maize seedlings were used.

Six treatments were established: control (neither addition of $\mathrm{Pb}$ or IAA), $250 \mu \mathrm{M}$ IAA, $500 \mu \mathrm{M}$ IAA, $20 \mu \mathrm{M} \mathrm{Pb}$ as $\mathrm{Pb}\left(\mathrm{NO}_{3}\right)_{2}$, $20 \mu \mathrm{M} \mathrm{Pb}+250 \mu \mathrm{M}$ IAA and $20 \mu \mathrm{M} \mathrm{Pb}+500 \mu \mathrm{M}$ IAA. For the treatment solutions $\mathrm{Ca}\left(\mathrm{H}_{2} \mathrm{PO}_{4}\right)_{2}$ was omitted to avoid the possibility of lead phosphate precipitation. Treatment solutions were changed daily. Seedlings were harvested after treatment for 1, 3 and 5 days, rinsed with deionized water, and separated into roots and shoots. The root and shoot samples were dried at $70{ }^{\circ} \mathrm{C}$ for 2 days and the content of metals including $\mathrm{Pb}$ was determined.

\subsection{Effect of cation channel blockers on Pb influx}

To better understand the transport pathway of the increased $\mathrm{Pb}$ influx, we examined the physiological functions of $\mathrm{Ca}^{2+}$ channel inhibitor of $\mathrm{La}^{3+}$ and $\mathrm{K}^{+}$channel inhibitor of $\mathrm{Cs}^{+}$. The original experiments were repeated with 10-day-old uniform maize seedlings, which were now incubated in $20 \mu \mathrm{M}$ Pb treatment solution amended with either $0.2 \mathrm{mM} \mathrm{La}^{3+}$ as $\mathrm{La}\left(\mathrm{NO}_{3}\right)_{3}$ or $\mathrm{Cs}^{+}$as $\mathrm{CsCl}$ for $4 \mathrm{~h}$. $\mathrm{La}\left(\mathrm{NO}_{3}\right)_{3}$ and $\mathrm{CsCl}$ have previously been identified as cation channel blockers by White (1997), who also reported appropriate application concentrations. The treatment with $20 \mu \mathrm{M} \mathrm{Pb}$ or $20 \mu \mathrm{M} \mathrm{Pb}+250 \mu \mathrm{M}$ IAA was used as a control.

\subsection{Influence of vanadate on Pb uptake}

The effect of vanadate on $\mathrm{Pb}$ uptake was examined by treating 10-day-old uniform maize seedlings with $0.1 \mathrm{mM}$ vanadate for $15 \mathrm{~min}$ and then exposing the seedlings to a $20 \mu \mathrm{M} \mathrm{Pb}$ treatment solution, as defined in Section 2.1, for an additional treatment period of $4 \mathrm{~h}$.

\subsection{Extraction of enzymes and activity assays}

\subsubsection{Extraction of enzymes}

Fresh root and shoot samples $(0.5 \mathrm{~g})$ from control and treated maize seedlings were ground in liquid nitrogen using a mor- 
tar and pestle. The ground samples were homogenized on an ice-bath in $10 \mathrm{~mL}$ of solution containing $50 \mathrm{mM}$ potassium phosphate buffer and $1 \%(\mathrm{w} / \mathrm{v})$ polyvinylpyrrolidone $(\mathrm{pH} 7.8)$ and were extracted at $4^{\circ} \mathrm{C}$. The homogenate was centrifuged at $8000 \times g$ for $15 \mathrm{~min}$ at $4{ }^{\circ} \mathrm{C}$. The supernatant was stored at $4{ }^{\circ} \mathrm{C}$ prior to analysis of the SOD, CAT and POD activities.

\subsubsection{SOD activity}

SOD activity was measured by the spectrophotometric method of Giannopolitis and Ries (1977). The assay was performed in terms of SOD's ability to inhibit reduction of $\rho$-nitroblue tetrazolium chloride (NBT) to formazan by the superoxide radical. One unit of SOD activity is defined as the amount of enzyme required to inhibit NBT reduction by $50 \%$ when measured at $560 \mathrm{~nm}$. All spectrophotometric analyses were conducted on an ultraviolet-visible spectrophotometer (U-3010, Hitachi Ltd., Tokyo, Japan).

\subsubsection{POD activity}

POD activity was assayed following the method of Polle et al. (1990). Changes in the absorbance of brown guaiacol at $460 \mathrm{~nm}$ in the presence of $\mathrm{H}_{2} \mathrm{O}_{2}$ were recorded for calculating POD activity. The enzyme activity was defined as the $\mathrm{nmol}$ of $\mathrm{H}_{2} \mathrm{O}_{2}$ oxidized $\mathrm{min}^{-1} \mathrm{mg}^{-1}$ protein.

\subsubsection{CAT activity}

CAT activity was assayed after Aebi (1983). A reaction mixture consisting of supernatant $(666 \mu \mathrm{L})$ and $73 \mathrm{mM} \mathrm{H}_{2} \mathrm{O}_{2}$ $(334 \mu \mathrm{L})$ was assayed for $3 \mathrm{~min}$ at $240 \mathrm{~nm}$. The activity was assayed by monitoring the decrease of absorbance as a consequence of $\mathrm{H}_{2} \mathrm{O}_{2}$ consumption. The enzyme activity was expressed as decomposed nmol of $\mathrm{H}_{2} \mathrm{O}_{2} \mathrm{~min}^{-1} \mathrm{mg}^{-1}$ protein.

\subsubsection{Soluble protein}

Total soluble protein content of the enzyme extracts were determined by reaction with Coomassie Brilliant Blue G-250 according to Bradford (1976) using bovine serum albumin (BSA) as a standard.

\subsubsection{Analysis of MDA in maize roots and shoots}

Lipid peroxidation in roots and shoots was measured in terms of MDA content by the thiobarbituric acid (TBA) reaction. The maize roots and shoots were homogenized in 5\% trichloroacetic acid (TCA) solution $(3 \mathrm{~mL})$. The homogenate was centrifuged at $2500 \times g$ for $10 \mathrm{~min}$ and the supernatant was assayed for MDA concentration according to the method of Heath and Packer (1968). MDA content was expressed as $\mathrm{nmol} \mathrm{g}^{-1}$ fresh weight (FW).

\subsection{Determination of metals}

Root and shoot samples were digested with $3 \mathrm{~mL}$ of concentrated $\mathrm{HNO}_{3}-\mathrm{HClO}_{4}(2: 1, \mathrm{v}: \mathrm{v})$ under high pressure conditions (Zhang and Shan, 1997). Concentrations of $\mathrm{Pb}, \mathrm{K}, \mathrm{Ca}, \mathrm{Mg}$, $\mathrm{Fe}, \mathrm{Mn}, \mathrm{Cu}$ and $\mathrm{Zn}$ in digested samples were determined by inductively coupled plasma-atomic emission spectrometry (ICP-AES) (Optima 2000 DV, Perkin-Elmer Co., Wellesley,
MA, USA). A certified reference material: peach leaves (GBW 08501, China) was used to ensure the quality of analyses. Good agreement was obtained between the determined and the certified values (data not shown).

\subsection{FTIR spectroscopic study}

A bundle of 10-day-old uniform maize seedlings were transferred to nutrient treatment solution with or without $20 \mu \mathrm{M}$ $\mathrm{Pb}, 250 \mu \mathrm{M}$ IAA or $20 \mu \mathrm{M} \mathrm{Pb}+250 \mu \mathrm{M}$ IAA. The seedlings were harvested 1 day after treatment. The fresh maize roots were freeze-dried and ground in an agate mortar and pestle. A portion of the ground roots $(1 \mathrm{mg})$ and $100 \mathrm{mg}$ of $\mathrm{KBr}$ (FTIR Grade, Alfa Aesar) were mixed and pressed into pellets. Infrared spectra were obtained on a Perkin-Elmer GX/2000 Fourier transform infrared (FTIR) spectrometer equipped with deuterated triglycine (DTGS) and mercury-cadmium-telluride (MCT) detectors, a $\mathrm{KBr}$ beam splitter and a sample bench purged with dry air. The resolution of FTIR spectra was $4.0 \mathrm{~cm}^{-1}$, and a total of 32 scans were collected for each spectrum. Spectral analysis was performed using OMNIC (Thermo Nicolet) software.

\subsection{Statistical analysis}

Data analysis was performed with Microcal origin 7.0 (Microcal Software, Northampton, MA, USA) or SPSS 12.0 for windows (SPSS, Chicago, IL, USA). Data were statistically evaluated by ANOVA and significant differences were assessed by Tukey's test. Comparison of multiple means was performed using Duncan's multiple range test with $P<0.05$. All values reported in this work were means of at least three independent experiments performed in triplicate.

\section{Results}

\subsection{Pb accumulation in maize as affected by IAA}

Table 1 shows $\mathrm{Pb}$ content as affected by IAA in both maize roots and shoots after 1, 3 and 5 days treatment. Compared to the $\mathrm{Pb}$ only treatment, exogenous IAA $(250$ and $500 \mu \mathrm{M})$ significantly increased $\mathrm{Pb}$ content in roots, but significantly decreased $\mathrm{Pb}$ content in shoots, especially for the treatment periods of 3 and 5 days. The $500 \mu \mathrm{M}$ IAA treatment triggered higher $\mathrm{Pb}$ content in roots and lowered $\mathrm{Pb}$ content in shoots, compared to the treatment of $250 \mu \mathrm{M}$ IAA. In maize roots application with 250 and $500 \mu \mathrm{M}$ IAA increased $\mathrm{Pb}$ content by 26 and 41,42 and 57, 78 and $144 \%$ after 1,3 and 5 days treatment, respectively, compared to the $\mathrm{Pb}$ only treatment. In contrast, the corresponding $\mathrm{Pb}$ content in maize shoots decreased by 27 and 43,41 and 60 , 34 and $47 \%$, after 1, 3 and 5 days treatment, respectively.

\subsection{Effects of cation channel blockers and vanadate on $P b$ uptake}

Fig. 1 shows the effects of $\mathrm{La}^{3+}$ (the $\mathrm{Ca}^{2+}$ channel inhibitor), $\mathrm{Cs}^{+}$(the $\mathrm{K}^{+}$channel inhibitor) and vanadate on $\mathrm{Pb}$ uptake and indicates that $\mathrm{La}^{3+}$ and $\mathrm{Cs}^{+}$significantly inhibited $\mathrm{Pb}$ influx 
Table 1

$\mathrm{Pb}$ contents $\left(\mu \mathrm{mol} \mathrm{g}^{-1} \mathrm{DW}\right)$ in the presence and absence of $250 \mu \mathrm{M}$ or $500 \mu \mathrm{M}$ IAA in maize roots and shoots after 1,3 and 5 days $(\mathrm{d})$ treatment

\begin{tabular}{|c|c|c|c|c|c|c|}
\hline \multirow[t]{2}{*}{ Treatment } & \multicolumn{3}{|l|}{ Root } & \multicolumn{3}{|l|}{ Shoot } \\
\hline & $1 \mathrm{~d}$ & $3 \mathrm{~d}$ & $5 \mathrm{~d}$ & $1 \mathrm{~d}$ & $3 \mathrm{~d}$ & $5 \mathrm{~d}$ \\
\hline $\mathrm{Pb}$ & $5.03 \pm 0.02$ & $10.64 \pm 0.04$ & $14.88 \pm 0.98$ & $0.79 \pm 0.02$ & $1.99 \pm 0.04$ & $3.55 \pm 0.07$ \\
\hline $\mathrm{Pb}+250 \mu \mathrm{M}$ IAA & $6.32 \pm 0.07$ & $15.02 \pm 0.03^{* *}$ & $26.42 \pm 0.05^{* *}$ & $0.58 \pm 0.04$ & $1.18 \pm 0.13^{*}$ & $2.33 \pm 0.16^{*}$ \\
\hline $\mathrm{Pb}+500 \mu \mathrm{M}$ IAA & $7.06 \pm 0.13^{*}$ & $16.65 \pm 0.14^{* *}$ & $36.33 \pm 0.18^{* *}$ & $0.45 \pm 0.03^{*}$ & $0.79 \pm 0.03^{* *}$ & $1.88 \pm 0.15^{*}$ \\
\hline
\end{tabular}

Values are means \pm S.D. $(n=3)$.

* Significant difference between $\mathrm{Pb}+\mathrm{IAA}$ and $\mathrm{Pb}$ treatments for $1,3,5$ days at $P<0.05$.

** Significant difference between $\mathrm{Pb}+\mathrm{IAA}$ and $\mathrm{Pb}$ treatments for $1,3,5$ days at $P<0.01$.

$(P<0.01)$. Compared to the controls of $20 \mu \mathrm{M} \mathrm{Pb}$ and $20 \mu \mathrm{M}$ $\mathrm{Pb}+250 \mu \mathrm{M}$ IAA, $\mathrm{La}^{3+}$ decreased the $\mathrm{Pb}$ content in maize roots by 61 and $59 \%$, respectively. Analogously, $\mathrm{Cs}^{+}$decreased the $\mathrm{Pb}$ content by 33 and $39 \%$, respectively. Pre-treatment of maize roots by vanadate, $\mathrm{a} \mathrm{H}^{+}$-ATPase inhibitor, for $15 \mathrm{~min}$, decreased $\mathrm{Pb}$ content in maize roots by 58 and $54 \%$, respectively, relative to the $20 \mu \mathrm{M} \mathrm{Pb}$, and $20 \mu \mathrm{M} \mathrm{Pb}+250 \mu \mathrm{M}$ IAA controls $(P<0.01)$.

\subsection{Antioxidant enzyme activity}

The activities of antioxidant enzymes SOD, POD and CAT in maize roots and shoots under $\mathrm{Pb}$, IAA or $\mathrm{Pb}+\mathrm{IAA}$ treatments are shown in Fig. 2. Although not statistically tested, the level of SOD activity in roots (Fig. 2A) was quite similar to that in shoots (Fig. 2B), while the level of POD activity in roots (Fig. 2C) was higher than in shoots. CAT activity (Fig. 2E) was lower in roots than in shoots (Fig. 2F). The SOD, POD and CAT activities in roots and shoots treated with $250 \mu \mathrm{M}$ IAA, $500 \mu \mathrm{M}$ IAA or $20 \mu \mathrm{M} \mathrm{Pb}$ steadily increased with increasing treatment time, and the highest activities were observed on day 5. On the 5 th day, SOD and POD activities with $\mathrm{Pb}+$ IAA treatments in roots were lower than either $\mathrm{Pb}$ or IAA only treatments. Results of SOD and POD activities in shoots were less definitive. CAT activities in roots with $\mathrm{Pb}+\mathrm{IAA}$ treatments were higher than CAT activities observed in either $\mathrm{Pb}$ or IAA only treatments, but conversely in shoots, CAT activities were lower in the $\mathrm{Pb}+\mathrm{IAA}$

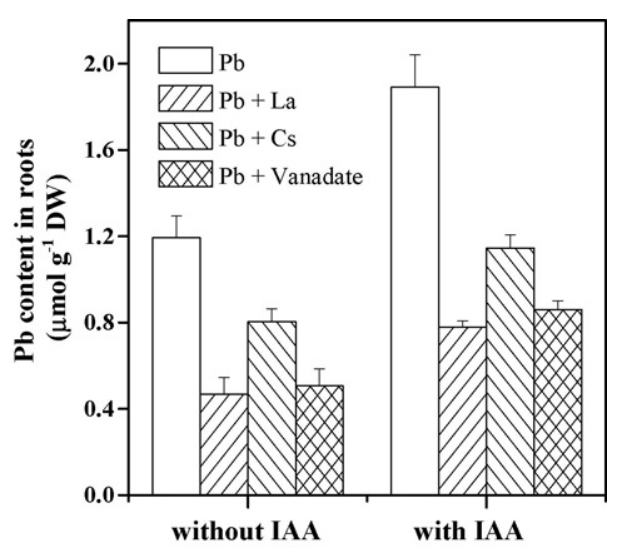

Fig. 1. Effect of cation channel inhibitors La, Cs and the $\mathrm{H}^{+}$-ATP inhibitor vanadate on $\mathrm{Pb}$ uptake in maize roots with and without $250 \mu \mathrm{M}$ IAA application. The uptake time is $4 \mathrm{~h}$. treatment when compared to either the $\mathrm{Pb}$ or IAA only treatments. The highest CAT activities were observed in roots treated with $\mathrm{Pb}+500 \mu \mathrm{M}$ IAA and these were 2.1, 5.8 and 3.9 times that of the CAT activities in the controls following treatment for 1 , 3 and 5 days, respectively. After the 3 and 5 days treatments, $\mathrm{CAT}$ activity in shoots with $\mathrm{Pb}$ or IAA treatments were significantly higher than CAT activity in the controls, while CAT activity in shoots with $\mathrm{Pb}+$ IAA was not significantly different from controls.

\subsection{Effect on lipid peroxidation}

Our results indicated a progressive increase in the MDA content of maize roots (Fig. $2 \mathrm{G}$ ) for $\mathrm{Pb}$ and IAA treatments from day 1 to 5. The MDA content of roots was higher than that of shoots from the third day. The increase in MDA content ranged from 1.2 to 4.2 and 1.3 to 2.2 times the controls in roots and shoots, respectively. In maize roots on day 1 a significant increase in MDA content compared to the control was observed only with $20 \mu \mathrm{M} \mathrm{Pb}+500 \mu \mathrm{M}$ IAA treatment. From day 3 all treatments significantly promoted MDA content.

\subsection{Effect on nutrition level}

There was a general decline of all the macro- and micronutrient levels in maize roots and shoots after $\mathrm{Pb}$, IAA or $\mathrm{Pb}+$ IAA treatments when compared to their respective controls (Tables 2 and 3 ). In roots, treatment with $\mathrm{Pb}$ only significantly decreased Mn content from day 3 to 5, but did not significantly decreased $\mathrm{K}$ content. Treatment with $\mathrm{Pb}$ only decreased Ca content in roots on day 5 . On day 5 , both the IAA and $\mathrm{Pb}+\mathrm{IAA}$ treatments caused a significant decrease in $\mathrm{K}, \mathrm{Ca}, \mathrm{Mn}$ and $\mathrm{Zn}$ contents of roots. Significant decreases in $\mathrm{Cu}$ and $\mathrm{Zn}$ contents were observed in maize shoots and roots due to IAA and $\mathrm{Pb}+\mathrm{IAA}$ treatments.

In shoots, treatment with $\mathrm{Pb}$ only resulted in a decrease in $\mathrm{Mn}$ content on day 5 and had no effect on the other nutrients during the whole treatment period. However, treatment with IAA only or $\mathrm{Pb}+\mathrm{IAA}$ caused significant decreases in $\mathrm{K}, \mathrm{Ca}, \mathrm{Mn}$ and $\mathrm{Cu}$ contents of the shoots. $\mathrm{Mg}$ and $\mathrm{Fe}$ contents in roots and shoots were not affected by $\mathrm{Pb}$, IAA or $\mathrm{Pb}+\mathrm{IAA}$ treatments.

Moreover, as to the general distribution of nutrients in roots and shoots for the six treatments, $\mathrm{Ca}, \mathrm{Mg}$ and $\mathrm{Zn}$ contents in roots were lower than those in shoots, while $\mathrm{Fe}$ and $\mathrm{Cu}$ contents in roots were higher than those in shoots. 

$\square$ control
$20 \mu \mathrm{MPb}$
包 $250 \mu \mathrm{M} \mathrm{IAA}$
目 $20 \mu \mathrm{M} \mathrm{Pb}+250 \mu \mathrm{M} \mathrm{IAA}$
四 $500 \mu \mathrm{M} \mathrm{IAA}$
耑 $20 \mu \mathrm{M} \mathrm{Pb}+500 \mu \mathrm{M}$ IAA
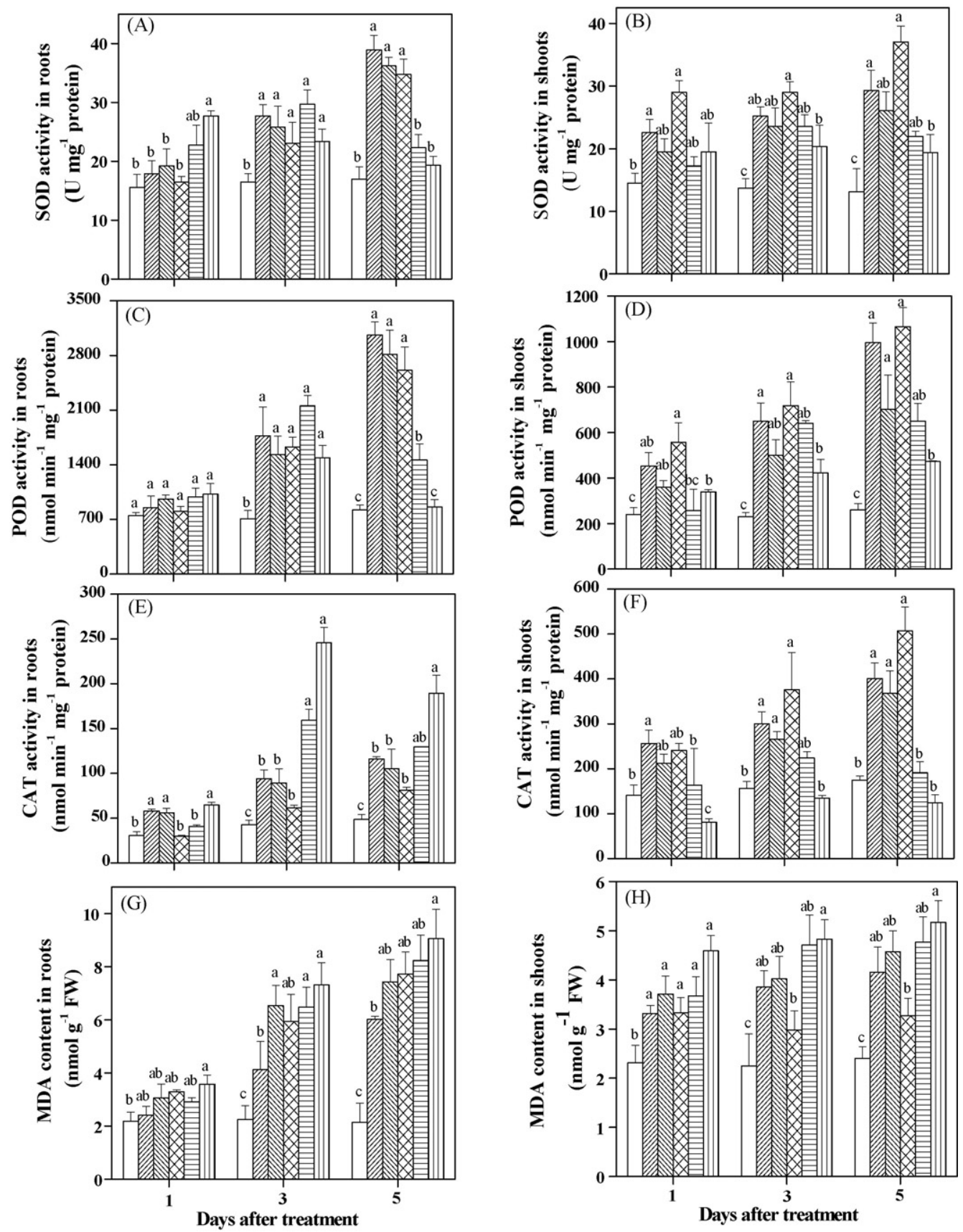

Fig. 2. SOD, POD, CAT activity and MDA content in maize roots (A, C, E, G) and shoots (B, D, F, H), respectively. The vertical bars represent means \pm S.D. of three experimental replicates $(n=3)$. Columns with different letters mean significant differences between the treatments on the same day according to Duncan's multiple range test $(P<0.05)$.

\subsection{FTIR spectral analysis}

The FTIR spectra of maize roots of control (a), treated with $250 \mu \mathrm{M}$ IAA (b), $20 \mu \mathrm{M} \mathrm{Pb}$ (c) and $20 \mu \mathrm{M} \mathrm{Pb}+250 \mu \mathrm{M}$ IAA (d) are shown in Fig. 3. The broad bands at 3373, 3381, 3363 and $3377 \mathrm{~cm}^{-1}$, respectively, are dominated by $-\mathrm{OH}$ stretching vibrations. Absorbance changes were observed at 1653, 1638, 1653 and $1642 \mathrm{~cm}^{-1}$, which were assigned to the antisymmet- rical $-\mathrm{COO}^{-}$stretching. The IAA and $\mathrm{Pb}+\mathrm{IAA}$ treatments resulted in a red shift of 15 and $11 \mathrm{~cm}^{-1}$, respectively, compared to the control, probably due to the conjunction of $-\mathrm{COOH}$ group and the formation of hydrogen bonds (H-bonds). The peaks at $1384,1383,1378$ and $1376 \mathrm{~cm}^{-1}$ are the vibrations of the $-\mathrm{NO}_{2}$ group. The $\mathrm{Pb}$ and $\mathrm{Pb}+\mathrm{IAA}$ treatments caused red shifts of 6 and $8 \mathrm{~cm}^{-1}$, respectively, when compared to the control. 
Table 2

Nutrient content ( $\left.\mu \mathrm{mol} \mathrm{g}^{-1} \mathrm{DW}\right)$ in maize roots with different treatment and exposure period, 1,3 and 5 days (d)

\begin{tabular}{|c|c|c|c|c|c|c|c|}
\hline Treatment & $\mathrm{K}$ & $\mathrm{Ca}$ & $\mathrm{Mg}$ & $\mathrm{Fe}$ & $\mathrm{Mn}$ & $\mathrm{Cu}$ & $\mathrm{Zn}$ \\
\hline \multicolumn{8}{|l|}{$1 \mathrm{~d}$} \\
\hline Control & $390.1 \pm 55.1$ & $50.5 \pm 3.4$ & $28.0 \pm 4.2$ & $7.04 \pm 1.33$ & $0.30 \pm 0.04$ & $0.59 \pm 0.07$ & $1.75 \pm 0.15$ \\
\hline $250 \mu \mathrm{M}$ IAA & $271.0 \pm 24.2$ & $45.7 \pm 1.3$ & $25.6 \pm 3.0$ & $5.10 \pm 1.48$ & $0.24 \pm 0.01$ & $0.47 \pm 0.14$ & $1.69 \pm 0.27$ \\
\hline $500 \mu \mathrm{M}$ IAA & $280.9 \pm 6.6$ & $56.5 \pm 4.4$ & $25.5 \pm 1.5$ & $6.15 \pm 1.22$ & $0.32 \pm 0.09$ & $0.58 \pm 0.05$ & $2.05 \pm 0.21$ \\
\hline $\mathrm{Pb}$ & $281.2 \pm 46.3$ & $54.7 \pm 6.5$ & $30.1 \pm 4.0$ & $9.33 \pm 2.36$ & $0.27 \pm 0.04$ & $0.60 \pm 0.02$ & $1.82 \pm 0.28$ \\
\hline $\mathrm{Pb}+250 \mu \mathrm{M}$ IAA & $272.5 \pm 37.5$ & $50.3 \pm 6.1$ & $23.3 \pm 1.9$ & $7.33 \pm 1.10$ & $0.24 \pm 0.07$ & $0.46 \pm 0.12$ & $1.70 \pm 0.41$ \\
\hline $\mathrm{Pb}+500 \mu \mathrm{M} \mathrm{IAA}$ & $212.4 \pm 6.8^{*}$ & $44.2 \pm 1.8$ & $24.4 \pm 1.3$ & $5.40 \pm 1.07$ & $0.23 \pm 0.02$ & $0.42 \pm 0.01$ & $1.72 \pm 0.21$ \\
\hline \multicolumn{8}{|l|}{$3 \mathrm{~d}$} \\
\hline Control & $537.6 \pm 12.9$ & $78.7 \pm 7.5$ & $32.1 \pm 6.3$ & $7.37 \pm 1.84$ & $0.75 \pm 0.11$ & $0.67 \pm 0.17$ & $1.76 \pm 0.42$ \\
\hline $250 \mu \mathrm{M}$ IAA & $508.7 \pm 6.9$ & $74.4 \pm 3.7$ & $28.1 \pm 2.7$ & $6.31 \pm 0.70$ & $0.42 \pm 0.09^{*}$ & $0.58 \pm 0.11$ & $1.45 \pm 0.31$ \\
\hline $500 \mu \mathrm{M}$ IAA & $406.6 \pm 75.1$ & $68.7 \pm 6.6$ & $30.1 \pm 2.3$ & $6.09 \pm 0.35$ & $0.36 \pm 0.01^{*}$ & $0.53 \pm 0.04$ & $1.28 \pm 0.21$ \\
\hline $\mathrm{Pb}$ & $473.4 \pm 11.1$ & $73.5 \pm 11.3$ & $35.5 \pm 4.6$ & $6.91 \pm 1.65$ & $0.39 \pm 0.10^{*}$ & $0.58 \pm 0.17$ & $1.29 \pm 0.23$ \\
\hline $\mathrm{Pb}+250 \mu \mathrm{M}$ IAA & $334.8 \pm 42.2$ & $68.1 \pm 5.9$ & $29.2 \pm 5.1$ & $4.90 \pm 1.48$ & $0.36 \pm 0.07^{*}$ & $0.61 \pm 0.12$ & $1.27 \pm 0.53$ \\
\hline $\mathrm{Pb}+500 \mu \mathrm{M} \mathrm{IAA}$ & $329.1 \pm 12.5^{*}$ & $69.4 \pm 8.7$ & $30.7 \pm 2.3$ & $5.99 \pm 1.51$ & $0.35 \pm 0.05^{*}$ & $0.56 \pm 0.17$ & $1.38 \pm 0.14$ \\
\hline \multicolumn{8}{|l|}{$5 \mathrm{~d}$} \\
\hline Control & $705.8 \pm 101.4$ & $69.2 \pm 7.5$ & $36.5 \pm 3.4$ & $6.92 \pm 0.71$ & $0.94 \pm 0.16$ & $0.63 \pm 0.14$ & $1.73 \pm 0.10$ \\
\hline $250 \mu \mathrm{M}$ IAA & $415.2 \pm 18.7^{*}$ & $50.6 \pm 9.1$ & $31.7 \pm 3.9$ & $7.30 \pm 0.68$ & $0.35 \pm 0.04^{*}$ & $0.50 \pm 0.08$ & $1.14 \pm 0.15^{*}$ \\
\hline $500 \mu \mathrm{M}$ IAA & $321.8 \pm 10.0^{* *}$ & $42.3 \pm 8.8^{*}$ & $35.9 \pm 3.1$ & $5.36 \pm 1.34$ & $0.25 \pm 0.03^{* *}$ & $0.40 \pm 0.07$ & $1.21 \pm 0.01$ \\
\hline $\mathrm{Pb}$ & $686.1 \pm 75.5$ & $47.3 \pm 13.1^{*}$ & $33.8 \pm 5.4$ & $6.18 \pm 1.73$ & $0.31 \pm 0.03^{* *}$ & $0.58 \pm 0.07$ & $1.26 \pm 0.13$ \\
\hline $\mathrm{Pb}+250 \mu \mathrm{M}$ IAA & $356.9 \pm 21.5^{* *}$ & $42.9 \pm 7.3^{*}$ & $26.4 \pm 1.0$ & $6.88 \pm 1.36$ & $0.24 \pm 0.02^{* *}$ & $0.48 \pm 0.03$ & $1.06 \pm 0.24^{*}$ \\
\hline $\mathrm{Pb}+500 \mu \mathrm{M} \mathrm{IAA}$ & $312.9 \pm 12.7^{* *}$ & $38.3 \pm 0.9^{*}$ & $27.5 \pm 3.8$ & $6.40 \pm 1.83$ & $0.25 \pm 0.03^{* *}$ & $0.47 \pm 0.02$ & $1.16 \pm 0.03$ \\
\hline
\end{tabular}

Data are means \pm S.D. $(n=3)$.

* Significant difference between IAA, $\mathrm{Pb}, \mathrm{Pb}+\mathrm{IAA}$ treatments and controls for given time and element at $P<0.05$.

** Significant difference between IAA, $\mathrm{Pb}, \mathrm{Pb}+\mathrm{IAA}$ treatments and controls for given time and element at $P<0.01$.

\section{Discussion}

Our results indicated that an exogenous plant growth regulator, IAA, affected $\mathrm{Pb}$ accumulation in maize seedlings. With the addition of IAA, $\mathrm{Pb}$ content in maize roots was significantly enhanced, but $\mathrm{Pb}$ content in maize shoots was significantly decreased (Table 1). It seems that the increased $\mathrm{Pb}$ accumulation, along with decreased $\mathrm{Ca}$ content in maize roots, may be a result of competition between $\mathrm{Pb}^{2+}$ and $\mathrm{Ca}^{2+}$ for binding sites on the transporting transmembrane proteins. Consequently,

Table 3

Nutrient content ( $\left.\mu \mathrm{mol} \mathrm{g}^{-1} \mathrm{DW}\right)$ in maize shoots with different treatment and exposure period, 1, 3 and 5 days (d)

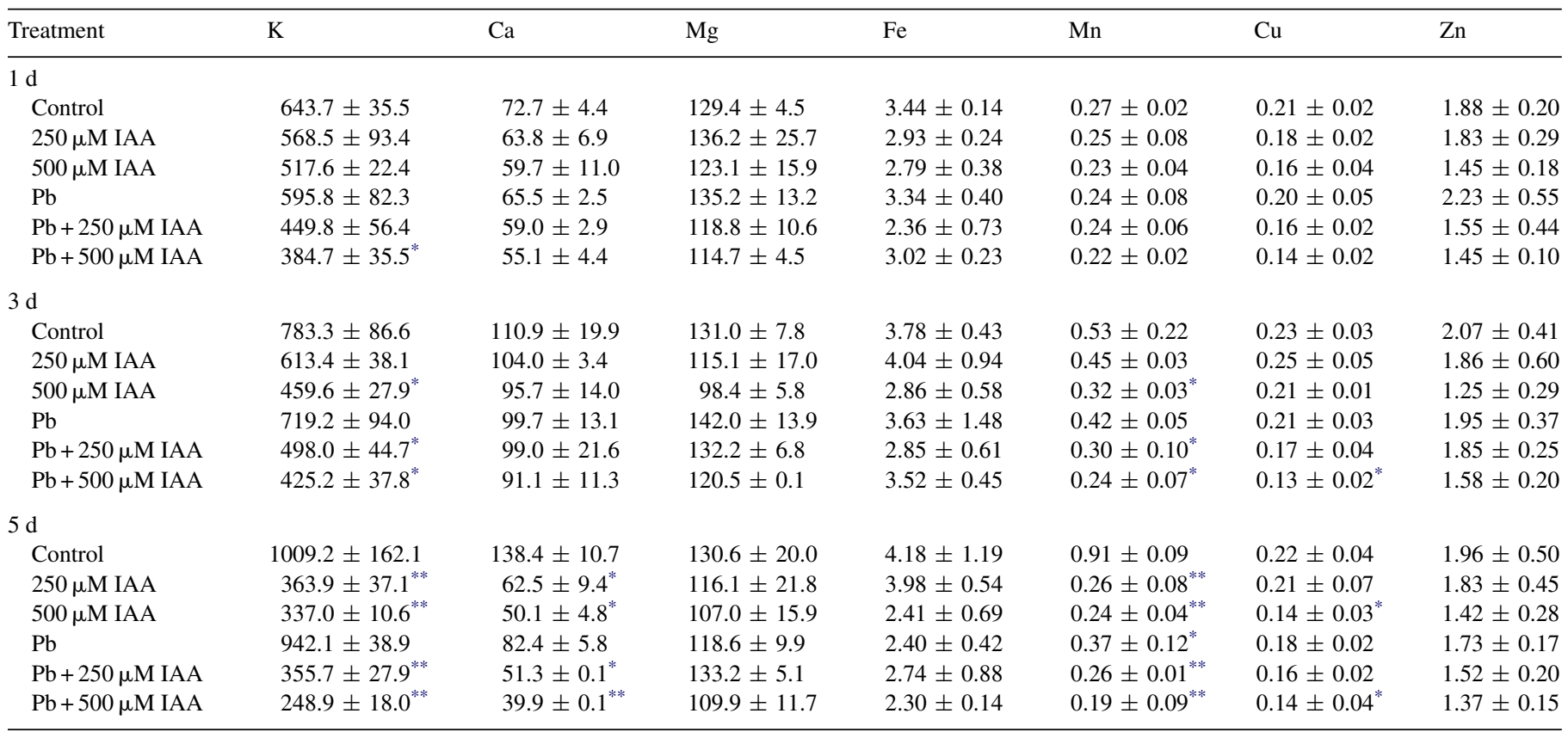

Data are means \pm S.D. $(n=3)$.

* Significant difference between IAA, $\mathrm{Pb}, \mathrm{Pb}+\mathrm{IAA}$ treatments and controls for given time and element at $P<0.05$.

** Significant difference between IAA, $\mathrm{Pb}, \mathrm{Pb}+\mathrm{IAA}$ treatments and controls for given time and element at $P<0.01$. 


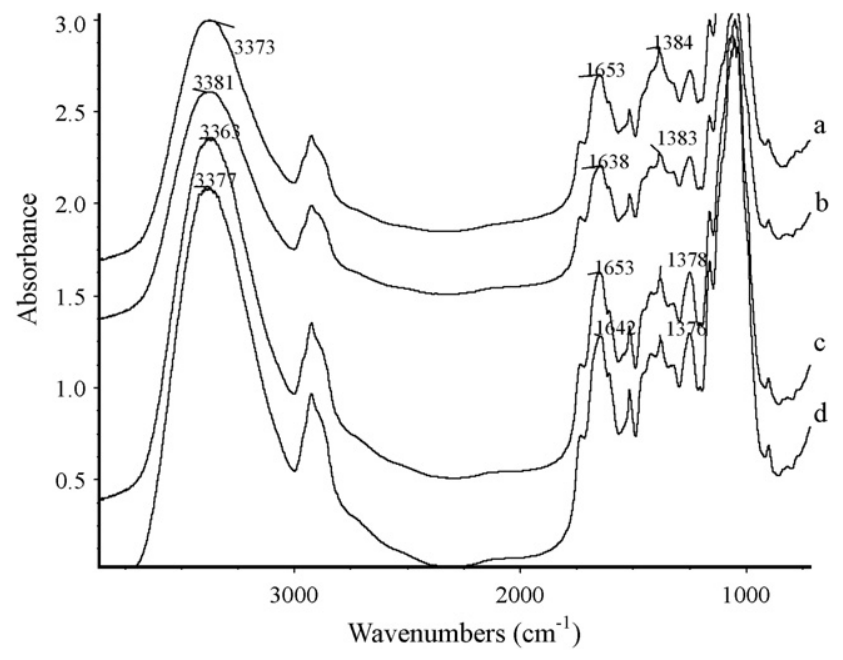

Fig. 3. FTIR spectra of maize roots after 1 day treatment: control (a), with $250 \mu \mathrm{M}$ IAA (b), $20 \mu \mathrm{M} \mathrm{Pb}$ (c) and $20 \mu \mathrm{M} \mathrm{Pb}+250 \mu \mathrm{M}$ IAA (d).

stronger $\mathrm{Pb}^{2+}$ interaction with the transporting proteins may result directly in the observed higher accumulation of $\mathrm{Pb}$.

It has been found that $\mathrm{Pb}$ significantly inhibited voltagegated $\mathrm{Ca}^{2+}$ channel activity in the plasma membrane of wheat roots (Huang and Cunningham, 1996). The inhibition of the Ca-channel by $\mathrm{Pb}^{2+}$ could result either from the competitive transport of $\mathrm{Pb}^{2+}$ through the Ca-channel or from its blockage by $\mathrm{Pb}$. In maize and wheat plasma membrane vesicles the $\mathrm{Ca}^{2+}$ channel is very sensitive to $\mathrm{La}^{3+}$ (Tyerman and Skerrett, 1999). Bregante et al. (1997) reported that $1 \mathrm{mM} \mathrm{Cs}^{+}$was able to block, in a very fast and voltage-dependent manner, up to $96 \%$ of the potassium current in protoplasts of maize roots. Our results suggest that $\mathrm{La}^{3+}$ and $\mathrm{Cs}^{+}$significantly inhibited the uptake of $\mathrm{Pb}$ by maize roots whether IAA was applied or not (Fig. 1). It is generally recognized that $\mathrm{Cs}^{+}$is a $\mathrm{K}^{+}$channel blocker, while not affecting any $\mathrm{Ca}^{2+}$ channels. $\mathrm{La}^{3+}$ is a broad range $\mathrm{Ca}^{2+}$ channel blocker, but also blocks non-selective cation channels, anion channels and metabolism. Interestingly, $\mathrm{Pb}^{2+}$ can bind to $\mathrm{Ca}^{2+}$-binding sites in regulatory proteins such as calmodulin. Recently, the tobacco plasma membrane protein $\mathrm{NtCBP} 4$ and the Arabidopsis gene $C N G C l$ were reported to be responsible for $\mathrm{Pb}^{2+}$ entry into plant cells (Sunkar et al., 2000). The involvement of $C N G C 1$ and $C N G C 2$ in the transport of potassium has also been reported (Leng et al., 1999). These previous results support our current findings that the uptake of $\mathrm{Pb}^{2+}$ was mediated, at least in part, by the $\mathrm{K}^{+}$and $\mathrm{Ca}^{2+}$ channels.

Uptake of cationic solutes is likely to be driven largely also by the negative membrane potential across the plasma membrane, which is generated in part by metabolically dependent processes such as proton extrusion via the plasma membrane $\mathrm{H}^{+}$-ATPase (Kochian, 1991). The pmf generated by plasma membrane $\mathrm{H}^{+}$-pumping ATPase powers transport through a variety of carriers. The plasma membrane $\mathrm{H}^{+}$-ATPase is a P-type ATPase. All P-type ATPase membranes are inhibited by orthovanadate $\left(\mathrm{H}_{2} \mathrm{VO}_{4}{ }^{-}\right)$. In our study, pre-treatment of maize roots by vanadate significantly inhibited $\mathrm{Pb}$ uptake with or without IAA application (Fig. 1), suggesting that the enhanced Pb uptake into the cytosol of maize protoplasts was dependent upon physiological functions of the plasma membrane P-type ATPase.

Some antioxidant enzymes have been stimulated by individual or joint stress of $\mathrm{Pb}$ and IAA (Fig. 2). The increase in SOD activity could possibly be a result of de-novo synthesis of enzyme protein (Shah et al., 2001). The activity of guaiacol peroxidase was also enhanced. This enzyme serves as an intrinsic defense tool to resist $\mathrm{Pb}$ and/or IAA induced oxidative stress. The role of peroxidases in responses to environmental stress in plants has been widely accepted (Castillo, 1986). In maize roots the SOD and POD activities with $\mathrm{Pb}+\mathrm{IAA}$ treatments were the same as those of $\mathrm{Pb}$ or IAA only treatments up to day 3 . After day 3, SOD and POD activities decreased and were lower than those of $\mathrm{Pb}$ or IAA only treatments on the day 5 . The decrease in SOD and POD activities with $\mathrm{Pb}+\mathrm{IAA}$ treatments was probably due to a decline in enzyme synthesis or a change in the assembly of enzyme subunits under $\mathrm{Pb}+\mathrm{IAA}$ stress. CAT activities in maize roots with $\mathrm{Pb}+\mathrm{IAA}$ treatments was consistently higher than either $\mathrm{Pb}$ or IAA only treatments, suggesting that CAT may be more tolerant to the joint stress of $\mathrm{Pb}$ and IAA than either SOD and POD, markedly elevating the capability of the plant to decompose $\mathrm{H}_{2} \mathrm{O}_{2}$ and protect the roots from $\mathrm{H}_{2} \mathrm{O}_{2}$ stress. In maize shoots, the SOD, POD and CAT activities with $\mathrm{Pb}+\mathrm{IAA}$ treatments were generally lower than the $\mathrm{Pb}$ or IAA only treatments presumably because $\mathrm{Pb}+\mathrm{IAA}$ caused heavier oxidative stress and inhibited the antioxidant defense mechanism. Even on day 5 the SOD, POD and CAT activities with most treatments (except CAT with $20 \mu \mathrm{M} \mathrm{Pb}+500 \mu \mathrm{M}$ IAA), whether in roots or shoots, were still higher than the controls, indicating that the antioxidant capacity was promoted. The response of maize to oxidative stress by $\mathrm{Pb}$ and/or IAA at the biochemical level was a process commencing as soon as treatment was initiated.

Lipid peroxidation is a biochemical marker for free radical mediated damage. The treatments with $\mathrm{Pb}$ and/or IAA induced oxidative stress in both maize roots and shoots as evidenced by increased MDA content compared to the controls. The oxidative stress was more severe in maize roots than in maize shoots. Moreover, MDA content with the $20 \mu \mathrm{M} \mathrm{Pb}+500 \mu \mathrm{M}$ IAA treatment was higher than that observed with the $\mathrm{Pb}$ only treatment (Fig. 2H), suggesting that exogenous IAA caused heavier oxidative stress to the $\mathrm{Pb}$ stressed maize seedlings.

The present results suggest a general decrease of nutrition content due to $\mathrm{Pb}$ and/or IAA treatments in maize seedlings (Tables 2 and 3). According to Huang and Cunningham (1996), treatment with $20 \mu \mathrm{M} \mathrm{Pb}$ significantly inhibited $\mathrm{Ca}, \mathrm{Mg}, \mathrm{K}$, $\mathrm{Fe}, \mathrm{Zn}$ and $\mathrm{Mn}$ accumulation in shoots of corn and ragweed (Ambrosia artemisiifolia $\mathrm{L}$.). $\mathrm{Pb}$ causes the imbalance of minerals $\mathrm{K}, \mathrm{Ca}, \mathrm{Mg}, \mathrm{Mn}, \mathrm{Zn}, \mathrm{Cu}$ and $\mathrm{Fe}$ within the tissues by physically blocking the access of these ions to the absorption sites of roots (Godbold and Kettner, 1991). On the other hand, a number of studies have shown that plant hormones in general, and auxins in particular, can significantly affect the uptake and further transport of nutrients within plants by regulating the sink action of developing tissues (Arteca, 1996; San-Francisco et al., 2005). Brummer and Parish (1983) hypothesized that an ionic gradient of the differential transmembrane, due to auxininduced transport processes, resulted in changes in permeability 
of various ions. Those previous studies supported our results (Tables 2 and 3). It can also be seen that in maize roots and shoots the levels of mineral nutrients with $\mathrm{Pb}+\mathrm{IAA}$ treatments were generally lower than $\mathrm{Pb}$ or IAA only treatments.

FTIR spectroscopy was used to clarify the reaction of $\mathrm{Pb}$ in maize roots (Fig. 3). The characteristic changes in the FTIR spectra were detected as a response to reactions between $\mathrm{Pb}$ and IAA. According to Kamnev et al. (2001), it is not the benzene ring in IAA but the IAA pyrrole moiety that is involved in coordination with $\mathrm{Fe}^{\mathrm{III}}$. Coordination is likely involved of the $\pi$-electron of the pyrrole ring conjugated with the non-shared electron pair at the heteroatom. The observed shift from 1653 to $1642 \mathrm{~cm}^{-1}$ was probably due to the coordination of $\mathrm{Pb}$ with the $-\mathrm{COOH}$ group of IAA.

We conclude that exogenous IAA significantly affected the patterns of $\mathrm{Pb}$ accumulation. Compared to $\mathrm{Pb}$ or IAA only treatments, IAA $+\mathrm{Pb}$ caused a synergistic effect on the oxidative stress on maize seedlings evidenced by higher MDA and lower nutrient contents. The increase in lipid peroxidation observed in this work could be considered as an indicator of oxidative stress caused by $\mathrm{Pb}$ and/or IAA. The antioxidant enzymes SOD, POD and CAT were stimulated to counteract the oxidative stress, which could serve as important indicator of an antioxidant defense mechanism.

\section{Acknowledgements}

This study was supported by the National Natural Science Foundation of China (Grant No. 20237010 and 20177030).

\section{References}

Aebi, H.E., 1983. Catalase. In: Bergmeyer, H.U. (Ed.), Methods of Enzymatic Analysis, third ed. Academic Press, NewYork, pp. 273-286.

Arteca, R.N., 1996. Plant Growth Substances. Chapman and Hall, New York.

Bradford, M.M., 1976. A rapid and sensitive method for the quantitation of microgram quantities of protein utilizing the principle of protein-dye binding. Anal. Biochem. 72, 248-254.

Bregante, M., Carpaneto, A., Pastorino, F., Gambale, F., 1997. Effects of monoand multi-valent cations on the inward-rectifying potassium channel in isolated protoplasts from maize roots. Eur. Biophys. J. 26, 381-391.

Brummer, B., Parish, R.W., 1983. Mechanisms of auxin-induced plant cell elongation. FEBS Lett. 161, 9 .

Cardinales, C., Put, C., Van Assche, F., Clijsters, H., 1984. The superoxide dismutase as a biochemical indicator discriminating between zinc and cadmium toxicity. Arch. Int. Physiol. Biochim. 92, 27-28.

Castillo, F.J., 1986. Extracellular peroxidases as markers of stress? In: Greppin, H., Penel, C., Gaspar, T. (Eds.), Molecular and Physiological Aspects of Plant Peroxidases. University of Geneva Press, Geneva, pp. 419-426.

Celik, I., Tuluce, Y., 2006. Effects of indoleacetic acid and kinetin on lipid peroxidation and antioxidant defense in various tissues of rats. Pestic. Biochem. Physiol. 84, 49-54.

De Melo, M.P., Escobar, J.A., Metodiewa, D., Dunford, H.B., Cilento, G., 1992. Horseradish peroxidase-catalysed oxidation of indole-3-acetic acid II: oxygen uptake nd chemiexcitation. Arch. Biochem. Biophys. 296, 34-39.

De Melo, M.P., de Lima, T.M., Pithon-Curi, T.C., Curi, R., 2004. The mechanism of indole acetic acid cytotoxicity. Toxicol. Lett. 148 (1-2), 103-111.

Giannopolitis, C.N., Ries, S.K., 1977. Superoxide dismutase in higher plants. Plant Physiol. 59, 309-314.

Godbold, D.L., Kettner, C., 1991. Lead influences root growth and mineral nutrition of Picea abies seedlings. J. Plant Physiol. 139, 95-99.
Halliwell, B., Gutteridge, J.M.C., 1999. Free Radicals in Biology and Medicine, third ed. Oxford University Press, New York.

Heath, R.L., Packer, L., 1968. Photoperoxidation in isolated chloroplasts. I. Kinetics and stoichiometry of fatty acid peroxidation. Arch. Biochem. Biophys. 125, 189-198.

Huang, J.W., Cunningham, S.D., 1996. Lead phytoextraction: species variation in lead uptake and translocation. New Phytol. 134, 75-84.

Joo, J.H., Yoo, H.J., Hwang, I., Lee, J.S., Nam, K.H., Bae, Y.S., 2005. Auxin-induced reactive oxygen species production requires the activation of phosphatidylinositol 3-kinase. FEBS Lett. 579, 1243-1248.

Kamnev, A.A., Shchelochkov, A.G., Perfiliev, Y.D., Tarantilis, P.A., Polissiou, M.G., 2001. Spectroscopic investigation of indole-3-acetic acid interaction of iron (III). J. Mol. Struct. 563-564, 565-572.

Kochian, L.V., 1991. Mechanisms of micronutrient uptake and translocation in plants. In: Mortvedt, J.J. (Ed.), Micronutrients in Agriculture. Soil Science Society of America, Madison, WI, pp. 251-270.

Leng, Q., Merier, R.W., Yao, W., Berkowits, G.A., 1999. Cloning and first functional characterization of a plant cyclic nucleotide-gated channel. Plant Physiol. 121, 753-761.

López, M.L., Peralta-Videa, J.R., Gardea-Torresdey, J.L., 2004. Using plant growth promoters for the enhancement of lead uptake by (Medicago sativa) alfalfa. In: SACNAS National Conference, Research Abstracts 1, p. 19.

López, M.L., Peralta-Videa, J.R., Benitez, T., Gardea-Torresdey, J.L., 2005. Enhancement of lead uptake by alfalfa (Medicago sativa) using EDTA and a plant growth promoter. Chemosphere 61, 595-598.

Lummerzheim, M., Sandroni, M., Castresana, C., De Oliveira, D., Van Montagu, M., Roby, D., Timmerman, B., 1995. Comparative microscopic and enzymatic characterization of the leaf necrosis induced in Arabidopsis thaliana by lead nitrate and by Xanthomanas campestris pv. Campestris after foliar spray. Plant Cell Environ. 18, 499-509.

Luna, C.M., González, C.A., Trippi, V.S., 1994. Oxidative damage caused by an excess of copper in oat leaves. Plant Cell Physiol. 35, 11-15.

Malecka, A., Jarmuszkiewicz, W., Tomaszewska, B., 2001. Antioxidative defense to lead stress in subcellular compartments of pea roots. Acta Biochim. Polon. 48, 687-698.

Mishra, A., Choudhuri, M.A., 1996. Possible implications of heavy metals $\left(\mathrm{Pb}^{2+}\right.$ and $\left.\mathrm{Hg}^{2+}\right)$ in the free radical mediated membrane damage in two rice cultivars. Indian J. Plant Physiol. 1, 40-43.

Polle, A., Chakrabarti, K., Schürmann, W., Rennenberg, H., 1990. Composition and properties of hydrogen peroxide decomposing systems in extracellular and total extracts from needles of Norway spruce (Picea abies L., Karst). Plant Physiol. 94, 312-319.

San-Francisco, S., Houdusse, F., Zamarreño, A.M., Garnica, M., Casanova, E., García-Mina, J.M., 2005. Effects of IAA and IAA precursors on the development, mineral nutrition, IAA content and free polyamine content of pepper plants cultivated in hydroponic conditions. Sci. Hortic. 106, $38-52$.

Shah, K., Kumar, R.G., Verma, S., Dubey, R.S., 2001. Effect of cadmium on lipid peroxidation, superoxide anion generation and activities of antioxidant enzymes in growing rice seedlings. Plant Sci. 161, 1135-1144.

Sunkar, R., Kaplan, B., Bouche, N., Arazi, T., Dolev, D., Talke, I.N., Maathuis, F.J.M., Sanders, D., Bouchez, D., Fromm, H., 2000. Expression of a truncated tobacco NtCBP4 channel in transgenic plants and disruption of the homologous Arabidopsis $C N G C 1$ gene confer $\mathrm{Pb}^{2+}$ tolerance. Plant J. 24, 533-542.

Tyerman, S.D., Skerrett, I.M., 1999. Root ion channels and salinity. Sci. Hortic. $78,175-235$.

Verma, S., Dubey, R.S., 2003. Lead toxicity induces lipid peroxidation and alters the activities of antioxidant enzymes in growing rice plants. Plant Sci. 164, 645-655.

White, P.J., 1997. Cation channels in the plasma membrane of rye roots. J. Exp. Bot. 48, 499-514.

Zacchini, M., Rea, E., Tullio, M., de Agazio, M., 2003. Increased antioxidative capacity in maize calli during and after oxidative stress induced by a long lead treatment. Plant Physiol. Biochem. 41, 49-54.

Zhang, S.Z., Shan, X.Q., 1997. The determination of rare earth elements in soil by inductively coupled plasma mass spectrometry. Atomic Spectrosc. 18, 140-144. 